\title{
Konservasi, Digitalisasi, dan Penyuluhan Naskah Kuno di Surau Manggopoh Kabupaten Agam
}

\author{
Taufiqurrahman $^{1^{*}}$, Ahmad Taufik Hidayat ${ }^{2}$ \\ ${ }^{1}$ UIN Imam Bonjol Padang \\ ${ }^{2}$ UIN Imam Bonjol Padang \\ Email: taufiqurrahman@uinib.ac.id ${ }^{1}$, ahmadtaufikhidayat@uinib.ac.id ${ }^{2}$ \\ *Corresponding author: taufiqurrahman@uinib.ac.id1 ${ }^{1}$
}

\begin{abstract}
ABSTRAK
Setelah gempa di Sumatera Barat 30 September 2009 banyak koleksi naskah menjadi rusak, bahkan masih ada masyarakat hanya ingin menyimpan naskah di rumah mereka. Sebagai warisan, dinamika naskah-naskah Islam berada dalam peradaban teks (hadhârah al-nash) selanjutnya diwariskan ke generasi sekarang, yang memuat informasi kehidupan manusia masa lalu. Sebagai sumber informasi berusia ratusan tahun, warisan yang terkandung di dalamnya menyimpan sebuah kearifan lokal, pesan leluhur, untuk menata kehidupan sekarang dan masa depan pokok-pokok pemikiran dalam berbagai disiplin ilmu. Pengabdian ini menggunanakan metode eksplorasi, identivikasi, digitalisasi, dan ceramah, tujuannya adalah membantu pewaris dalam merawat naskah, menumbuhkan kesadaran masyarakat pewaris naskah pentingnya merawat, teknik dan cara-cara melindungi naskah, dan memperpanjang usia naskah melalui proses alih media dalam format digitalisasi. Kesimpulan dari kegiatan pengabdian ini ada dua belas naskah dikonservasi dan diidentivikasi judul dan ringkasan isinya, dibuat dalam bentuk digital, selanjutnya disimpan di dalam lemari yang layak.
\end{abstract}

Kata Kunci: Koleksi naskah; warisan; kearifan lokal

\begin{abstract}
After the earthquake in West Sumatra on 30 September 2009, many manuscripts were damaged, even some people just wanted to keep the manuscript in their homes. As a legacy, the dynamics of Islamic texts are in the civilization of texts (hadhârah al-nash) then passed on to the present generation, which contains information on past human life. As a source of information for hundreds of years, the inheritance contained in it holds local wisdom, ancestral message, to organize the present life and future points of thought in various scientific disciplines. This service uses exploration, identification, digitalization, and lecture methods, the aim of which is to assist the testator in caring for the manuscript, to raise public awareness of the importance of the heir to the manuscript, the techniques and ways to protect the manuscript, and to extend the life of the manuscript through the process of media transfer in digitized format. The conclusion from this community service activity was twelve manuscripts were conserved and the titles and contents of the contents were identified, made in digital form, then stored in a proper cupboard.
\end{abstract}

Keywords: Manuscript collection; legacy; local wisdom 


\section{PENDAHULUAN}

Keberadaan naskah kuno di Minangkabau tidak bisa dipungkiri. Koleksi dan penemuan naskah oleh para filolog Sumatera Barat membuktikan bahwa Minangkabau sangat kaya akan budaya tertulis. Dokumen tertulis ini adalah bukti tingginya peradaban Minangkabau. Seperti penelitian yang telah dilakukan oleh Yusuf dkk. pada tahun 2006, telah dijumpai ada sekitar 284 naskah Minangkabau yang tersebar di hampir semua wilayah alam Minangkabau (masih banyak dalam koleksi pribadi/pewaris naskah) (Yusuf 2006). Setelah itu, muncul juga beberapa katalog-katalog serupa untuk mendokumentasikan naskah Minangkabau yang masih tersimpan, antara lain Katalog Naskah Lubuk Landur (Hidayat, Putra, and C. 2011; Hidayatullah 2017), dan Katalog Naskah Klasik Minangkabau koleksi Fakultas Adab dan Humaniora (Riza 2013). Dimungkinkan, masih banyak katalog-katalog naskah Minangkabau lainnya yang juga bermunculan dan belum diterbitkan.

Terkait dengan kondisi naskah tersebut di atas, maka kegiatan pengabdian ini merupakan upaya menyelamatkan naskah kuno yang ditemukan di situs surau Manggopoh, Kabupaten Agam. Jenis kegiatan ini adalah kegiatan yang sama dengan yang diadakan oleh sejumlah lembaga di wilayah Sumatera Barat (Akhimuddin 2012; Hidayatullah 2017). Berdasarkan tuasi di lokasi, naskah di surau Manggopoh di Kabupaten Agam belum ditangani dengan baik bahkan setelah gempa 7,9 skala Richter pada 30 September 2009 (Syarif 2015, 93-99). Naskah-naskah itu terabaikan di ruang lantai dua dengan tumpukan buku cetak sebagai rekam jejak kegiatan pendidikan di masjid ini di masa lalu. Kondisi ini sangat berbahaya bagi naskah-naskah di sana karena menyatu dengan teks cetak yang rentan terhadap kerusakan.

Ruang yang tersedia untuk menyimpan naskah juga tidak memadai dalam hal pengaturan ruang. Ruangan ini berada di sebelah jendela sehingga udara yang masuk bercampur dengan embun bahkan dengan cipratan hujan. Ketika udara panas, kondisi ini justru akan mempercepat proses penghancuran. Atas dasar itu, kami dari tim pengabdian mengambil inisiatif untuk melestarikan warisan budaya naskah dengan memfasilitasi tempat yang ramah terhadap naskah.

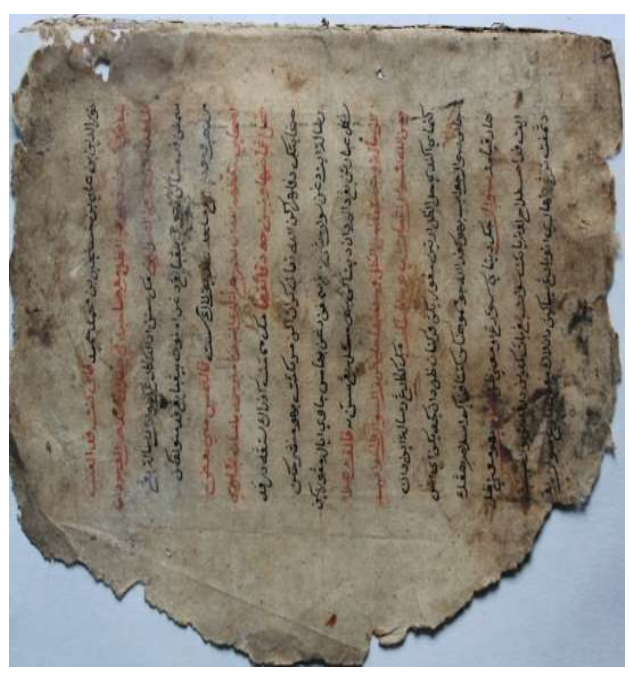




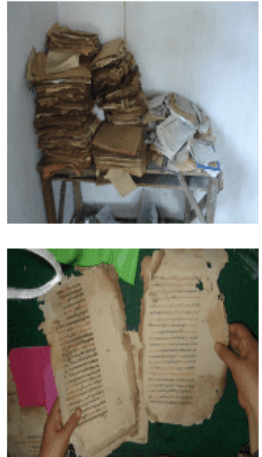

Koleksi Naskah di
Surau Manggopoh
tidak tersimpan
dengan baik dan
dibiarkan terbengkalai
di Lantai II di
bangunan terpisah
dari Surau Manggopoh
Kondisi ini
membahayakan
naskah yang
menyebabkan banyak
naskah menjadi rusak

Gambar 1: Contoh Naskah yang Rusak

Menanggapi kondisi ini, tim pengabdian berkoordinasi dengan masyarakat untuk mendapatkan lemari kaca sebagai tempat menyimpan naskah serta untuk mengatur ulang penempatan naskah tersebut. Dengan demikian, kegiatan penyelamatan melalui konservasi, digitalisasi, dan penyuluhan teks yang disimpan dilakukan secara bertahap, lebih serius, dan terus menerus. Berdasarkan hal ini, tujuan dari pengabdian ini adalah: 1) Membantu pewaris naskah dalam mengelola aset lokal dalam bentuk naskah, sehingga usia naskah dapat diperpanjang dengan menyediakan ruang (lemari etalase) dan peralatan yang dibutuhkan untuk merawat naskah; 2) Meningkatkan kesadaran masyarakat pewaris naskah tentang pentingnya perawatan, teknik, dan cara-cara untuk melindungi naskah dari kerusakan. Membuat situs untuk menyimpan naskah sebagai rumah untuk koleksi naskah yang telah digunakan sebagai sumber pendidikan di masa lalu; 3) Memperpanjang usia naskah melalui proses mentransfer media dalam format digital.

\section{METODE PENELITIAN}

Pengabdian masyarakat ini menggunakan metode eksplorasi, identivikasi, digitalisasi, dan ceramah (J. Moleong 2002; Sutopo 1988). Dalam memberikan penyuluhan, tim pengabdi menggunakan metode ceramah untuk menyampaikan pesan dan manfaat dari kegiatan ini bagi surau mereka (Baried 1994; Fathurahman 2013; Pudjiastuti 2007). Kemudian, dalam melaksanakan kegiatan, tim menggunakan metode identivikasi dan eksplorasi untuk setiap naskah yang kemudian akan didigitalkan sehingga hasil akhirnya adalah dalam bentuk software (Arsyad 2013; Duff 2013).

Persiapan, pelaksanaan, dan pelaporan kegiatan pengabdian masyarakat ini dimulai pada bulan Juni hingga Oktober 2019. Berikut ini adalah matriks kegiatan:

\begin{tabular}{|c|c|c|c|c|c|c|}
\hline \multirow{2}{*}{ No } & \multirow{2}{*}{ KEGIATAV } & \multicolumn{5}{|c|}{ BULAN } \\
\hline & & Juni & Juli & Agustus & September & Oktober \\
\hline 1. & Persiapan Proposal & & & & & \\
\hline 2. & Survey Awal & & & & & \\
\hline \multirow[t]{4}{*}{3.} & Pengabdian & & & & & \\
\hline & a. Konservasi & & & & & \\
\hline & b. Digitalisasi & & & & & \\
\hline & c. Penyuluhan & & & & & \\
\hline 4. & Penulisan Laporan & & & & & \\
\hline
\end{tabular}

HASIL DAN PEMBAHASAN

A. Hasil 
Istilah "naskah" (manuskrip) (Inggris: manuskript; Belanda: handscrift; Arab: nuskhah almakhtûtât) dipahami sebagai tulisan tangan; sastra lama; mengandung konsep budaya lama. Dalam Kamus Bahasa Indonesia dijumpai defenisi "manuskrip tulisan tangan, baik dengan pena, pensil atau diketik (tidak dicetak)" (Sugono 2008, 987). Kata "diketik" dalam definisi kamus ini sedikit menyimpang dari definisi awal "naskah tulisan tangan", juga tidak sejalan dengan karakteristik naskah secara umum, atau makna yang dikemukakan oleh para ahli (Baried 1994; Lubis 1996).

$\begin{array}{llr} & \text { Pengertian naskah } & \text { kuno } \\ \text { dalam Undang-undang } & \text { negara } \\ \text { Republik Indonesia, } & \text { tepatnya }\end{array}$
Undang-undang Republik Indonesia Nomor 43 tahun 2007 tentang Perpustakaan bab I pasal 1 ayat 4 diidentifikasi sebagai "semua dokumen tertulis yang tidak dicetak atau tidak diperbanyak dengan cara lain, baik yang berada di dalam negeri maupun di luar negeri yang berumur sekurang-kurangnya 50 (lima puluh) tahun, dan yang mempunyai nilai penting bagi kebudayaan nasional, dan ilmu pengetahuan."Pengertian tentang naskah ini disertai dengan amanat bagi masyarakat untuk melestarikan dan mendaftarkannya ke Perpustakaan Nasional Republik Indonesia, sebagaimana tertuang dalam Bagian kedua tentang kewajiban pasal 6 ayat (1) b yang berbunyi: masyarakat berkewajiban "menyimpan, merawat dan melestarikan naskah kuno yang dimilikinya dan mendaftarkannya ke Perpustakaan Nasional.”

Adapun konteks kegiatan ini, terminologi yang dimaksud adalah karya tulisan tangan para penyalin, penulis, sastrawan, pemikir, dan cendekiawan.

Selain itu, sebagai benda warisan budaya yang terbuat dari organik (sebagian besar kertas sebagai alasnya), naskah kuno sangat rentan terhadap kerusakan, terutama jika berada dalam kondisi yang tidak dirawat. Ini juga sama halnya dengan kondisi objektif masyarakat Minangkabau saat ini, terutama setelah gempa bumi, yang semakin mengancam keberlanjutan naskahnaskah ini. Oleh karena itu, penyelamatan naskah harus lebih ditingkatkan melalui kegiatan konservasi, digitalisasi, dan penyuluhan berkelanjutan (FA 2008).

Dalam ilmu filologi, naskah merupakan salah satu dari dua objek kajiannya (Baried 1994; Lubis 1996; Yudiafi 2011). Objek lainnya adalah teks. Naskah merupakan bentuk fisik dari naskah yang bersifat konkrit sehingga ia dapat dilihat, diraba, dan diukur bentuknya. Sementara itu, teks merupakan kandungan dari sebuah naskah. Ia bersifat abstrak karena berisi dengan pemikiranpemikiran penulis naskah yang tidak dapat dilihat, diraba atau pun diukur bentuknya. Hal-hal yang terkait dengan naskah adalah segala hal 
yang berhubungan dengan fisiknya antara lain ukuran naskah, ukuran blok teks, warna tinta, huruf atau aksara yang digunakan, jumlah halaman, jumlah baris per halaman, bahasa penuturan, alas naskah, hiasan naskah, dan kolofon. Ilmu yang membahas segala aspek dari naskah ini disebut dengan kodikologi.

Kodikologi berasal dari bahasa Latin yaitu codex dalam bentuk tunggal dan codies dalam bentuk jamaknya. Dalam bahasa Indonesia, codex dimaknai dengan naskah (Yudiafi 2011). Kodikologi mengacu kepada segala pembahasan tentang kodeks atau naskah yang berhubungan dengan fisiknya seperti silsilah kepemilikan, jumlah hasil salinan, dan jenis alas yang digunakan untuk menuangkan pemikiran penyalin baik itu berupa kertas atau media lainnya (Děroche 2005).

Alphonse Dain, seorang ahli bahasa Yunani, merupakan orang yang pertama kali mengemukakan istilah kodikologi dalam kuliahkuliahnya di Ecole Normale Superieure, Paris, pada Februari 1944. Pada tahun 1949, ia menulis sebuah tulisan yang berjudul Les Manuscripts. Sejak saat itulah, istilah kodikologi mulai dikenal di kalangan yang lebih luas. Menurutnya, kodikologi merupakan sebuah ilmu yang membahas tentang fisik dari naskah bukan isi yang tersimpan di dalam naskah tersebut. Kodikologi bukanlah ilmu baru tetapi istilahnya saja yang baru dikenal oleh kalangan yang lebih luas (Yudiafi 2011).

Itulah sebabnya, banyak hal yang dapat dibahas tentang fisik dari naskah antara lain skriptorium atau tempat penyimpanan naskah, alas naskah, cap kertas, usia naskah, penulisan dan penyalinan naskah, serta hiasan naskah. Karena kegiatan pengabdian ini berhubungan dengan hiasan-hiasan yang tersimpan di dalam naskah, maka penjelasannya akan diuraikan dalam penjelasan tersendiri.

Beragam upaya yang dilakukan oleh pecinta naskah telah dilakukan. Baik itu dilakukan oleh kelompok maupun perorangan. Baik juga kegiatan ini didanai, maupun juga dengan mengeluarkan dana pribadi. Kecintaan terhadap warisan leluhur ini membuat siapa saja akan tergerak hatinya untuk menyelamatkan. Upaya yang pernah dilakukan adalah preservasi, konservasi, restorasi, dan digitalisasi naskah. Tiga istilah pertama merupakan upaya penyelamatan naskah jika ia berada dalam kondisi yang mengkhawatirkan sehingga dilakukan penyelamatan berupa pembersihan debu dan perbaikan bentuk yang sudah merapuh. Digitalisasi naskah merupakan upaya untuk mengalihmediakan sehingga dapat dibaca tanpa merusak fisik naskah itu sendiri.

Melalui kegiatan pengabdian ini diharapkan aspek-aspek yang terkait dapat dicapai, yaitu: 
1. Mempermudah perawatan benda-benda cagar budaya, pendataan dan pelacakan terhadap sumber-sumber primer bagi sejumlah penkajian. Tempat yang memadai, direkam dalam format digital tentu akan mempermudah akses bagi masyarakat luas, terutama peneliti, dosen, mahasiswa dan semua pihak yang memiliki consern dalam bidang pernaskahan dalam pemanfaatannya.

2. Memperbanyak data primer dalam pengkajian Islam di wilayah nusantara pada umumnya dan wilayah Minangkabau secara khusus.

3. Menumbuhkan kesadaran masyarakat luas terhadap peninggalan karya-karya tertulis masa lalu.

Dalam kenyataan kondisi di lapangan yang ditemukan, bahwa ada sejumlah teks di Surau Manggopoh yang terabaikan, disebabkan oleh hal-hal berikut ini:

Pertama, para ahli waris naskah tidak memiliki cukup peralatan, tempat, dan terutama dana untuk membeli infrastruktur, sehingga perlu dibantu oleh instansi atau lembaga lain sehingga naskah yang sebenarnya memiliki nilai historis tinggi dapat dikelola dengan baik.
Kedua, ada indikasi kesalahpahaman dari orang-orang yang mewarisi naskah, sehingga mereka tidak merasa perlu untuk mempertahankan naskah dengan benar. Ini juga menunjukkan kurangnya penyuluhan yang dilakukan oleh instanso atau lembaga terkait seperti universitas, museum, perpustakaan daerah dan lainnya karena kurangnya informasi tentang keberadaan naskah.

Ketiga, naskah-naskah yang berada di lokasi sangat mendesak untuk ditransfer dalam bentuk digital karena usia dan kondisi naskah yang rentan terhadap kerusakan alam. Selain itu, naskah yang ada saat ini dikhawatirkan akan dicuri oleh pihak yang tidak bertanggung jawab (Fathurahman and Loir 1999; Zakaria 2019). Dengan demikian, pemindahan media dalam bentuk digitalisasi jelas sangat penting untuk dilakukan.

Seiring dengan terdatanya kekayaan alam Minangkabau berupa dokumen ini, maka banyak juga dilakukan pelestarian karena tidak semua naskah yang ditemukan di lapangan berada dalam kondisi yang baik. Banyak naskah yang ditemukan sudah tidak dapat dibaca lagi karena proses penyimpanan yang tidak baik. Koleksi yang beraksara Arab dan Arab Melayu ini dianggap sakral oleh pewaris naskah sehingga ia tidak pernah dibuka bahkan dibaca. Naskah-naskah ini disimpan di tempat 'aman' bagi mereka, antara lain di dalam peti dan di atas loteng 
rumah. Melihat kondisi alam Indonesia, penyimpanan dengan cara demikian tentu tidak akan ramah untuk dokumen berbahan kertas ini. Kondisi alam hanya akan semakin memperburuk keadaannya sehingga menyebabkan informasi yang tersimpan di dalam manuskrip akan menjadi hilang.

Berikut ini adalah langkahlangkah yang telah dilakukan dalam kegiatan pengabdian di Surau Manggopoh:

Langkah 1: Tim melakukan survei lapangan tentang keberadaan koleksi naskah milik Surau Manggopoh. Pada langkah awal ini, tim memperoleh informasi bahwa Surau memiliki koleksi di dalam dan di luar surau mengingat banyaknya siswa yang belajar kepada Syekh Surau Manggopoh pada masa dahulu. Kunjungan ini dilakukan pada 6-7 Juli 2019.

Langkah 2: Tim mulai melaksanakan konservasi dan mendigitalkan naskah dalam upaya untuk menyelamatkan naskah yang masih layak disimpan. Beberapa nasakah tidak dapat lagi disimpan karena kondisi fisik naskah yang sudah rusak. Beberapa naskah juga ada yang tenggelam karena banjir yang melanda Nagari Manggopoh di Kabupaten Agam sekitar 2 tahun yang lalu. Selain itu, naskah juga tidak disimpan dengan baik karena pengaruh cuaca ekstrem. Pada kesempatan ini, tim berhasil mendigitalkan sebanyak 12 nasakah kuno dalam bentuk kepingan CD.
Tim pengabdi melakukan kegiatan ini pada 17-18, 24-25 Agustus, dan 07-08, 14-15 September 2019.

Langkah 3: Tim pengabdi melakukan penyuluhan serta menyerahkan lemari etalase sebagai bentuk pelestarian naskah dalam rangka memberika pelayanan kepada masyarakat. Lemari etalase ini digunakan sebagai tempat menyimpan naskah untuk kemudian ditempatkan dan dikelola oleh pewaris pewaris. Tim pengabdi melakukan kegiatan ini pada 12-13 Oktober 2019.

Berdasarkan langkah-langkah kegiatan tersebut, maka kegiatan pengabdian masyarakat di Surau Manggopoh Kabupaten Agam menghasilkan output sebagai berikut:

\section{Konservasi}

Penyelamatan naskah kuno dari kepunahan, kerusakan fisik dan penelantaran yang tidak semestinya (Akhimuddin 2012; Iswanto 2016). Dengan kegiatan konservasi, naskah ditempatkan di lemari, dengan pengaturan dan pembungkus yang dapat memperpanjang umur naskah, dan tentu saja berdampak pada pelestarian nilai-nilai budaya.

Kegiatan konservasi dimulai dengan memberikan penyuluhan dan kesadaran akan pentingnya makna naskah-naskah kuno kepada masyarakat (termasuk pearis naskah), sehingga ada keinginan mereka untuk mengumpulkan dan menyimpannya di suatu tempat. Kegiatan ini telah dimulai melalui eksplorasi sekitar Juni hingga Juli 
2019 di Surau Manggopoh, Kabupaten Agam.

Dari kegiatan-kegiatan tersebut diperoleh informasi mengenai keberadaan naskah lain serta ada hubungan langsung dengan pewaris naskah surau Manggopoh. Menurut informan dan pewaris naskah, sekitar 25 buah naskah kuno dari koleksi Surau Manggopoh tersedia untuk didigitalkan (Ismet 2019). Namun, naskah yang ditemukan hanya 12 karena naskah yang tersebar di masyarakat masih perlu dieksplorasikan. Bahkan naskah yang sebelumnya merupakan koleksi dari Surau Manggopoh juga telah dibawa oleh siswa sehingga sulit dilacak. Akhirnya, hanya 12 naskah yang bisa didigitalkan. Naskahnya adalah: Naskah Sufisme terdiri dari 3 naskah; naskah Fiqh berjumlah 2 buah; naskah Bahasa Arab bernomor 3 buah; naskah Tafsir berjumlah 2 buah; naskah Mantiq bernomor 1 buah; dan naskah Tauhid berjumlah 1 buah (kutipan dari manuskrip ini terlampir).

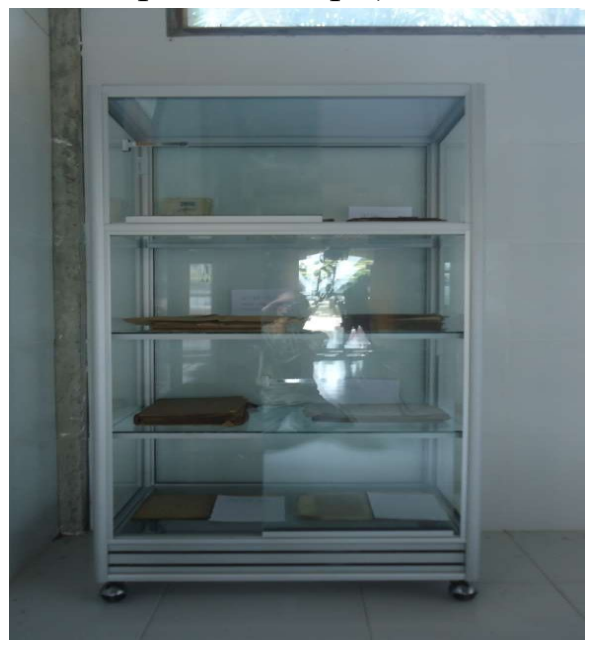

Gambar 2: Lemari Etalase Naskah
Dalam melakukan kegiatan konservasi naskah tersebut, tim telah mempersiapkan peralatan, yaitu: Kain alas 1 x 1 m, kuas halus, sarung tangan karet, dan masker. Apabila ditemukan naskah dalam keadaan rusak parah, maka tim melakukan konservasi lanjutan dengan menggunakan peralatan, yaitu: Jarum jahit, benang, cmc, kertas tisu jepang, cutter, dan penggaris.

Selanjutnya, tim juga melakukan deskripsi naskah dengan menggunakan peralatan lembar deskripsi, alat tulis, dan alat ukur (penggaris/meteran).

\section{Digitalisasi}

Tim pengabdi melaksanakan kegiatan mendigitalkan 12 naskah di Surau Manggopoh untuk menghasilkan output dalam bentuk versi digital dari naskah. Setelah itu, kegiatan dilanjutkan dengan menyimpan naskah di tempat yang tepat, yaitu lemari penyimpanan naskah yang akan dianggarkan dalam kegiatan ini serta membeli alat perawatan untuk naskah (kuas, sampul, dll.) (Duff 2013; Hunter 2017; Soemantri 2019).

Pemindahan naskah kuno ke dalam format digital sebanyak 24 unit CD yang terdiri dari 12 naskah kuno. Dengan adanya naskah versi digital ini, maka diharapkan naskah yang telah dilestarikan tidak perlu dibuka setiap saat. Hal ini bertujuan untuk menghindari penggunaan langsung naskah, sehingga juga dapat memperpanjang umur naskah. 
Oleh sebab itu, ketika melaksanakan kegiatan digitalisasi, tim menggunakan peralatan, yaitu: Kamera, laptop, alas naskah (menggunakan kain hitam supaya kontras dengan naskah saat dilakukan pemotretan), dan spatula kecil (alat yang digunakan ketika membuka lipatan ujung naskah)

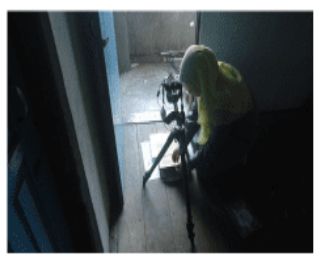

Digitalisasi dilakukan untuk

mendokumenkan fisik naskah yang belum terlalu rusak agar dapat dibaca secara digital.

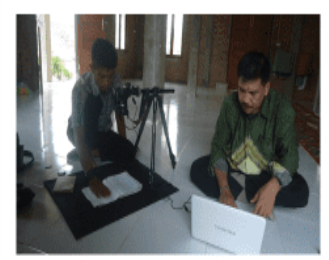

Naskah-naskah yang telah dibersihkan akan difoto dan disimpan di dalam sebuah CD (Compact Disk).

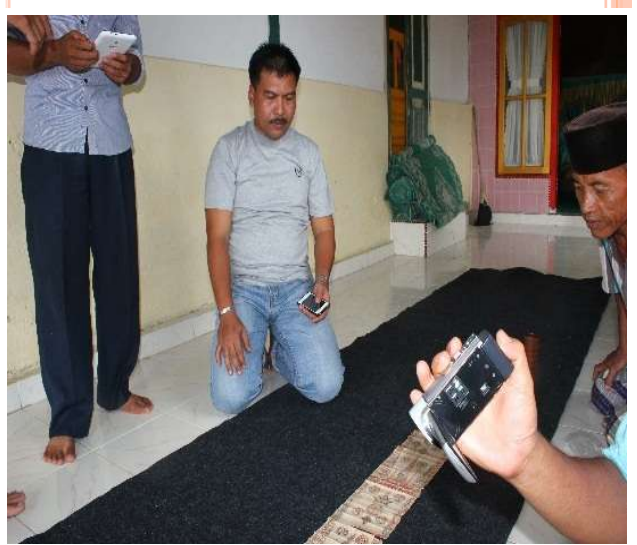

Gambar 3: Kegiatan Digitalisasi Naskah

\section{Penyuluhan}

Melalui penyuluhan nasakah, tim telah berupaya untuk membangkitkan kesadaran yang tinggi bagi ahli waris naskah dan masyarakat di lingkungan sosial naskah tentang makna keberadaan naskah yang perlu dijaga dari waktu ke waktu (Agusta 2013; N, Listihana, and Nofrizal 2019; Schwab 2016).

Penyuluhan yang tim lakukan dituju kepada para pewaris naskah (orang yang diamanahkan menjaga naskah) serta masyarakat sekitar, dengan melaksanakan diskusi (FGD) serta ceramah secara berkala.

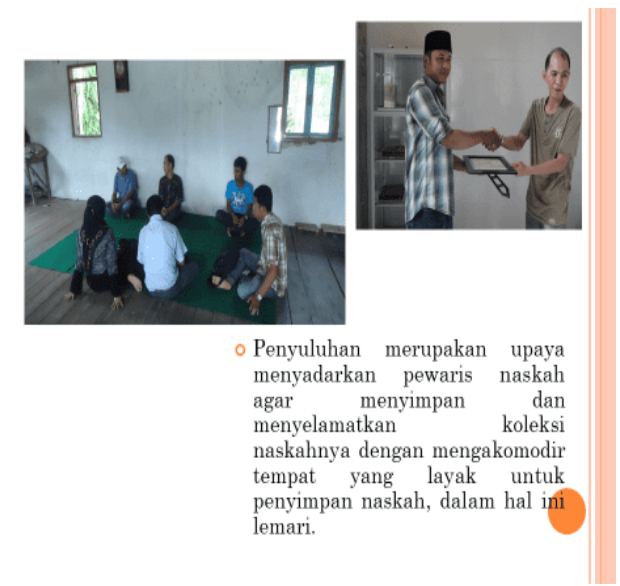

Gambar 4: Kegiatan Penyuluhan Naskah

\section{B. Pembahasan}

Kegiatan

pengabdian masyarakat dalam bentuk konservasi, digitalisasi, dan penyuluhan yang dilakukan di Surau Manggopoh, Kabupaten Agam ini berjalan dengan baik. Ahli waris naskah, Zahmas Ari Tuanku Sidi, menerima dengan baik dan mempercayakan koleksi naskahnya untuk dilestarikan dan didigitalkan oleh tim pengabdian. (Tuanku Sidi 2019). Meskipun demikian, kegiatan pengabdian masyarakat ini bukan berarti tidak menjumpai kendala ataupun hambatan. Berikut ini adalah faktorfaktor yang mendukung dan menghambat yang dihadapi oleh tim dalam kegiatan pengabdian masyarakat ini, yaitu:

1. Faktor Pendukung 
Faktor yang mendukung pelaksanaan pengabdian kepada masyarakat dalam bentuk konservasi, digitalisasi, dan penyuluhan di Kabupaten Surau Manggopoh adalah sebagai berikut:

a. Adanya dukungan positif dari ahli waris naskah dan masyarakat setempat dalam kegiatan ini sehingga naskah yang mereka miliki dapat dilestarikan.

b. Adanya antusiasme dari masyarakat setempat untuk melestarikan naskah yang mereka miliki dengan menyimpannya di tempat yang layak.

2. Faktor Penghambat

Faktor yang menghambat pelaksanaan kegiatan ini adalah sebagai berikut:

a. Adanya beberapa pemilik naskah dalam komunitas masyarakat setempat yang tidak ingin dan tidak mempercayakan naskah mereka untuk dilestarikan serta didigitalkan oleh tim karena faktor sakral yang mereka pahami.

b. Kurangnya kesadaran dari ahli waris naskah untuk menyimpan naskah yang rapi yang telah dilestarikan sebelum fasilitas atau prasarana penyimpanan disediakan. Hal ini menyebabkan tim bekerja dua kali dalam melakukan konservasi.

Dalam kegiatan pengabdian ini juga dilakukan evaluasi terhadap kegiatan yang dilakukan. Evaluasi ini dilakukan pada tahap akhir kegiatan. Evaluasi diberikan dengan mengumpulkan data dari setiap langkah yang dilakukan dalam kegiatan ini. Evaluasi dilakukan dalam bentuk survei ulang terhadap naskah koleksi Surau Manggopoh melalui kegiatan mencatat informasi tentang jumlah naskah di Surau. Selama kunjungan tim pengabdi, informan memberi tahu komitmen masyarakat sekitar bahwa mereka masih menyimpan beberapa naskah karena sebelumnya mereka belajar Islam di Surau Manggopoh.

Evaluasi pada tahap kedua, dilakukan dengan memisahkan teks yang masih bisa disimpan dan teks yang tidak bisa lagi disimpan. Naskah yang masih bisa disimpan didigitalkan untuk menghasilkan 12 salinan dalam bentuk softcopy. Naskah yang tidak bisa diselamatkan lagi dilestarikan dan dipisahkan sehingga rayap yang telah memakan kertas tidak bergerak.

Evaluasi akhir adalah penyerahan lemari etalase sebagai bentuk prasarana yang lebih efektif untuk menyimpan dan mengkoleksi naskah. Dengan upaya ini, usia naskah akan diperpanjang.

Dalam konteks pelestarian naskah, sebagaimana tertuang dalam Undang-undang Negara Republik Indonesia tahun 2007 tentang perpustakaan, bagian kedua pasal 7 
ayat (1) d., negara menegaskan bahwa "negara menjamin ketersediaan keragaman koleksi perpustakaan melalui terjemahan (translasi), alih aksara (transliterasi), alih suara ke tulisan (transkripsi), dan alih media (transmedia)". Selanjutnya, sebagai bentuk apresiasi dari negara, maka pemerintah juga memberikan reward kepada orangorang yang telah memberikan perhatian kepada naskah kuno dengan redaksi dalam Undangundang Negara Republik Indonesia tahun 2007 tentang perpustakaan, bagian kedua pasal 7 ayat (1) i.: "negara memberikan penghargaan kepada setiap orang yang menyimpan, merawat, dan melestarikan naskah kuno.”

Sebagai upaya pelestarian (dalam arti luas) pengabdian ini pada dasarnya menyambut himbauan pemerintah sebagaimana termaktub dalam Undang-undang Negara Republik Indonesia tersebut di atas.

Alasan mendasar kegiatan ini karena memperhatikan keberadaan naskah kuno merupakan produk intelektual yang diwariskan kepada masyarakat sekarang. Teks-teks yang ditulis di dalamnya lahir lewat serangkaian proses kreatif tokohtokoh penulis masa lalu, seperti ulama, sastrawan, pemikir maupun ilmuwan yang mencoba menuangkan gagasan-gagasan, ide-ide, konsepkonsep dan karya-karya mereka pada zaman lampau. Jejak-jejak tulisan di dalamnya merupakan dokumentasi konkret dari upaya-upaya mereka dalam hal ini. Oleh karena itu, mengkajinya dalam sebuah penelitian adalah upaya lebih jauh dari sekedar pelestarian, namun juga merevitalisasi nilai-nilai luhur yang telah dikembangkan oleh nenek moyang bangsa Indonesia.

Apabila dilihat arah Pengembangan ranah kajian pada UIN Imam Bonjol Padang setidaknya mempunyai tiga landasan: Kultural, sosiologis, dan yuridis. Secara kultural adalah dengan mengombinasikan kajian lokalitaspartikular seperti dunia pernaskahan dengan globalisme universal. Adapun secara sosiologis diharapkan keberadaan khazanah budaya dan agama dapat berbaur secara sinergis dalam bingkai Negara Kesatuan Indonesia. Sedangkan secara yuridis, landasan pengembangan ranah kajian ini berdasarkan kepada visi UIN Imam Bonjol Padang "menjadi Universitas Islam yang kompetitif di ASEAN tahun 2037," sebagaimana tertera dalam Peraturan Menteri Agama Republik Indonesia Nomor 28 Tahun 2017 tentang Statuta UIN Imam Bonjol Padang Bab I, pasal 3. Dalam uraian selanjutnya pada pasal 4 dijelaskan tentang misi UIN Imam Bonjol terwujudnya sarjana yang beriman, berilmu, dan berbudaya (Peraturan Menteri Agama Republik Indonesia Nomor 28 Tahun 2017 tentang STATUTA UIN Imam Bonjol Padang). Visi misi ini menuntut dipetakannya ranah kajian yang berhubungan dengan lokal konten seperti manuskrip yang 
diharapkan menjadi penciri atau model UIN Imam Bonjol Padang.

Apabila digali lebih jauh, berbagai cabang dan konten di atas juga mengandung aspek yang luas dan saling terhubung. Dalam naskah tasauf, misalnya terdapat kajian yang berhubungan dengan filsafat, hadis, tafsir, sejarah, bahasa, sastra dan lain-lain. Menurut teori integral G. Koster, sebagaimana dikutip dalam Braginsky keterhubungan semacam ini secara teori dimaknai sebagai perpaduan antara fungsi faedah atau-dengan sedikit perbedaan--fungsi penyempurnaan rohani versi Braginsky dengan fungsi pelipur lara (Braginsky 1998). Sifat keluasan dan saling terhubung tersebut merupakan hasil refleksi dari pengalaman panjang masyarakat Muslim Nusantara tentang keislaman dan nilai-nilainya, yang pada gilirannya bermuara pada 'kesadaran diri' naskah-naskah tersebut. Islam dalam berbagai aspek ajarannya yang terekam dalam naskah kuno tersebut, berkembang secara luas dalam berbagai pengalaman intelektual masyarakat muslim pada masa lalu. Wujud kesadaran diri ini lah yang dapat digali dalam kerangka disiplin ilmu yang dikembangkan di UIN Imam Bonjol Padang, yang nantinya dapat dimanfaatkan sebagai sumbersumber penting dalam riset-riset dosen, maupun mahasiswanya.

Sejauh ini, riset-riset dan pengabdian yang dihasilkan oleh Dosen, Peneliti dan Mahasiswa belum banyak mengeksplorasi naskah-naskah Minangkabau dalam berbagai aspeknya. Kegiatan pengabdian ini dimaksudkan membantu penyediaan data manuskrip bagi para Dosen, Peneliti dan Mahasiswa di lingkungan UIN Imam Bonjol Padang, menawarkan pemetaan yang relevan dengan sejumlah bidang kajian di lingkungan UIN Imam Bonjol Padang yang mengacu pada objek, konten, lokus dan pemikiran ulama dan para penulis pada masa lalu.

\section{SIMPULAN}

Pelaksanaan pengabdian dalam pelestarian naskah koleksi Surau Manggopoh di Kabupaten Agam dapat disimpulkan cukup berhasil hingga tahap penyelamatan berupa penyediaan prasarana penyimpanan yang ramah terhadap naskah. Selain itu, kegiatan ini juga telah berhasil membuat salinan softcopy dari semua koleksi naskah yang ada. Keberhasilan ini ditunjukkan sebagai berikut.

1. Sebanyak dua belas naskah telah dilestarikan dan diidentivikasi judul dan ringkasan isinya. Bahkan naskah tersebut telah berhasil didigitalkan pada $24 \mathrm{CD}$.

2. Naskah yang telah berhasil dilestarikan dan didigitalkan disimpan dalam lemari etalase yang sesuai sebagai fasilitas yang disediakan oleh tim pengabdian. 
Tanggapan dari ahli waris naskah dan masyarakat setempat bahwa kurangnya perhatian pemerintah terhadap warisan budaya dalam bentuk dokumentasi naskah. Oleh karena itu, kami memberikan saran kepada pemerintah dan lembaga terkait untuk lebih bijak dalam menanggapi hasil warisan budaya lokal, terutama mengenai naskah. Hal ini akan membuat orang lebih termotivasi untuk menyimpan teks koleksi pribadi mereka.

\section{DAFTAR PUSTAKA}

Agusta, Leonando. 2013. "Pengaruh Pelatihan dan Motivasi Kerja terhadap Kinerja Karyawan CV Haragon Surabaya." Agora 1(3): 1399-1408.

Akhimuddin, Yusri. 2012. "Naskah [Asal Khilaf Bilangan Taqwim]: Relasi UlamaUmara Di Minangkabau Abad Ke-17 Dalam Penetapan Awal Ramadan." Manuskripta.

Arsyad, Azhar. 2013. "Media Pembelajaran." Rajagrafindo Persada.

http://www.rajagrafindo.co.id /produk/media-pembelajaran/ (July 13, 2019).

Baried, Siti Baroroh. 1994. Pengantar Teori Filologi. Cet. II. Yogyakarta: Badan Penelitian dan Publikasi Fakultas Sastra, Universitas Gadjah Mada.

Braginsky, Vladimir. 1998. Yang Indah Berfaedah Dan Kamal, Sejarah Sastera Melayu Dalam Abad 7-19. Jakarta: INIS.

Děroche, F. 2005. Islamic Codicology. London: Al-
Furqan Islamic Heritage Foundation.

Duff, Alistair S. 2013. Information Society Studies. Routledge.

FA, Wiranto. 2008. Perpustakaan Dalam Dinamika Pendidikan Dan Kemasyarakatan: Dilengkapi Dengan UU No.43 Tahun 2007 Tentang Perpustakaan.

Fathurahman, Oman. 2013. "A Textual Approach to Understanding Nusantara Muslims." Studia Islamika 20(1).

http://journal.uinjkt.ac.id/inde x.php/studia-

islamika/article/view/353

(July 9, 2020).

Fathurahman, Oman, and Henri Chambert Loir. 1999. Khazanah Naskah: Panduan Koleksi Naskah-Naskah Indonesia Sedunia. Jakarta: Yayasan Obor Indonesia.

Hidayat, A.T., A. Putra, and Ahmad C. 2011. Katalog Naskah Pasaman Surau Lubuk Landur Dan Mesjid Syekh Bonjol. Jakarta: Tinta Mas Indonesia.

Hidayatullah, Dede. 2017. "NASKAH ILMU MA'RIFATULLAH: KODIKOLOGI, SUNTINGAN, STRUKTUR, DAN ISI TEKS The Manuscript of Ilmu Ma'rifatullah: Codicology, Editing, Structure, and Content." METASASTRA: Jurnal Penelitian Sastra.

Hunter, Eric J. 2017. Classification Made Simple: An Introduction to Knowledge Organisation and Information Retrieval. Routledge. 
Ismet, Buya. 2019. "Wawancara Pribadi Dengan Buya Ismet, 17 Agustus 2019, Surau Manggopoh Agam."

Iswanto, 2016. "KECENDERUNGAN KAJIAN MANUSKRIP KEISLAMAN DI UIN SYARIF HIDAYATULLAH JAKARTA." Al-Qalam.

J. Moleong, Lexy. 2002. Metode Penelitian Kualitatif. Bandung: Remaja Rosdakarya. http://perpustakaan.bppsdmk. kemkes.go.id//index.php? $\mathrm{p}=\mathrm{s}$ how detail\&id=5816.

Lubis, Nabilah. 1996. Naskah, teks, dan metode penelitian filologi. Forum Kajian Bahasa \& Sastra Arab, Fakultas Adab IAIN Syarif Hidayatullah.

N, Arizal, Wita Dwika Listihana, and Nofrizal Nofrizal. 2019. "Mendeley: Untuk Meningkatkan Kemampuan Menulis Dosen.” Aksiologiya: Jurnal Pengabdian Kepada Masyarakat 3(2): 106-112112.

Pudjiastuti, Titik. 2007. "Kajian Kodikologis Atas Surat Sultan Kanoman, Cirebon (COD. OR. 2241 ILLB 17 (No. 80))." Wacana, Journal of the Humanities of Indonesia.

Riza, Yulfira. 2013. Katalogus Naskah Klasik Islam. Jakarta: PT Tinta Mas Indonesia.

Schwab, Klaus. 2016. "The Fourth Industrial Revolution." : 172.

Soemantri, Sandha. 2019. "Pelatihan Membuat Media Pembelajaran Digital."
Aksiologiya: Jurnal Pengabdian Kepada Masyarakat 3(1): 64-69-69. Sugono, D. 2008. Kamus Bahasa Indonesia. 4th ed. Jakarta: Pusat Bahasa Depatemen Pendidikan Nasional.

Sutopo, Heribertus. 1988. Pengantar Penelitian Kualitatif: DasarDasar Teoritis Dan Praktis. Surakarta: UNS Press.

Syarif, Viola Dwi Putri. 2015. "PERAN PEMERINTAH

DALAM

MENYELAMATKAN

NASKAH KUNO

MINANGKABAU PASCA

GEMPA PADANG UNTUK

PELESTARIAN BUDAYA

MASYARAKAT

MINANGKABAU - PDF

Free Download."

https://docplayer.info/791878

32-Peran-pemerintah-dalammenyelamatkan-naskah-

kuno-minangkabau-pascagempa-padang-untukpelestarian-budayamasyarakatminangkabau.html (July 11, 2019).

Tuanku Sidi, Zahmas Ari. 2019. "Wawancara Pribadi Dengan Pewaris Naskah, 12 Oktober 2019, Manggopoh Agam."

Yudiafi, S.Z. 2011. Filologi. Jakarta: Universitas Terbuka.

Yusuf, M. 2006. Katalogus Manuskrip Dan Skriptorium Minangkabau. Japan: Tokyo University of Foreign Studies.

Zakaria, Ismail. 2019. "Pramono Menyelamatkan Naskah Kuno Minangkabau." Kompas.id. https://kompas.id/baca/utama/ 
2019/01/28/pramonomenyelamatkan-naskahkuno-minangkabau/ (July 14, 2019).

\section{LAMPIRAN NASKAH:}

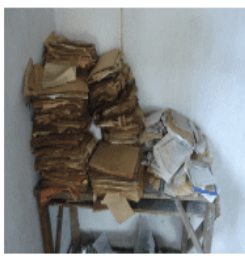

$>$ Koleksi Naskah di

Surau Manggopoh

tidak tersimpan

dengan baik dan

dibiarkan terbengkalai

di Lantai II di

bangunan terpisah

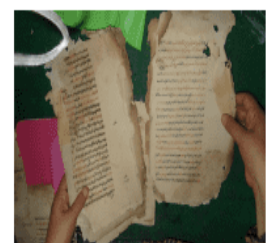

dari Surau Manggopoh

$>$ Kondisi

ini

membahayakan

naskah yang

menyebabkan banyak naskah menjadi rusak
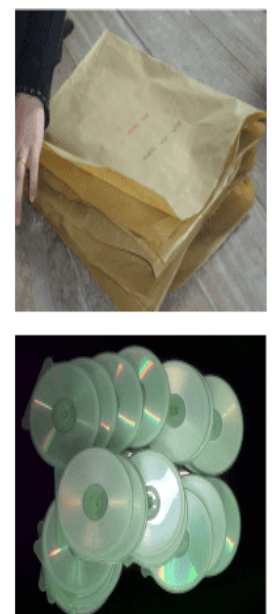

- Naskah ditemukan berjumlah 12 buah.

o Seluruh naskah yang menjadi koleksi surau tersebut telah selesai dibersihkan dan telah didigitalisasi sehingga menghasilkan 24 keping CD.

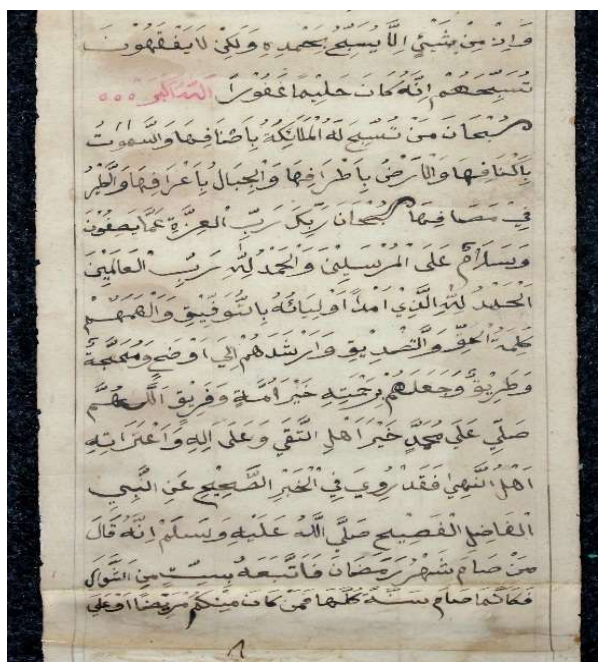

Gambar Naskah Tauhid

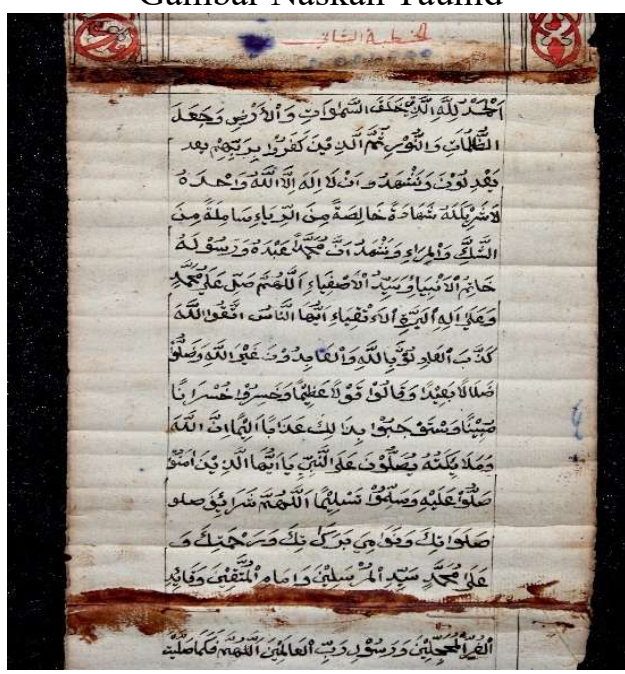

Gambar Naskah Tafsir

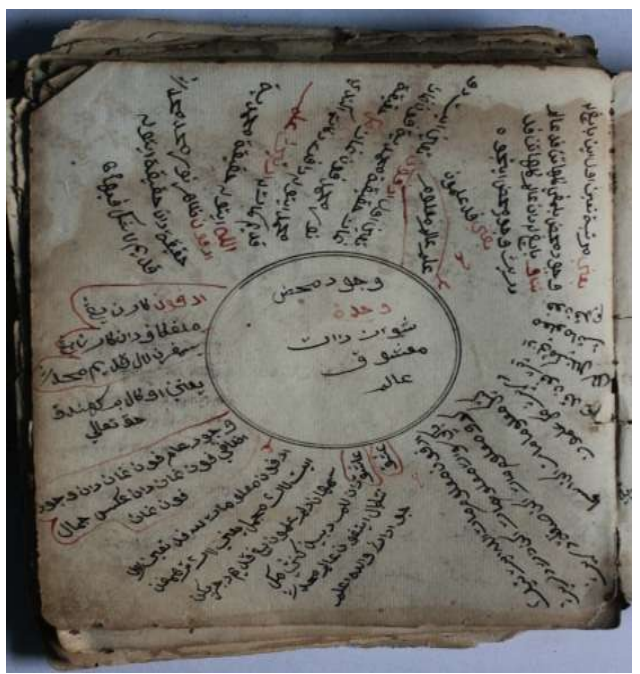

Gambar Naskah Tasawuf 


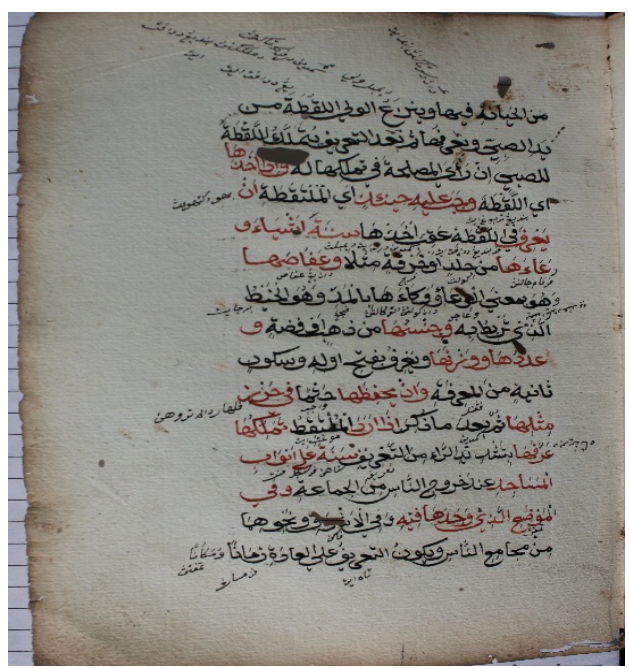

\section{Gambar Naskah Fiqh}

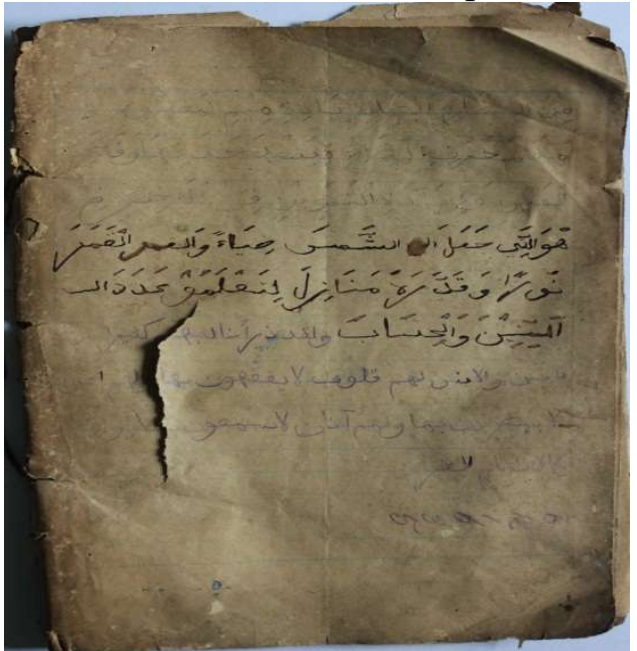

Gambar Naskah Bahasa Arab

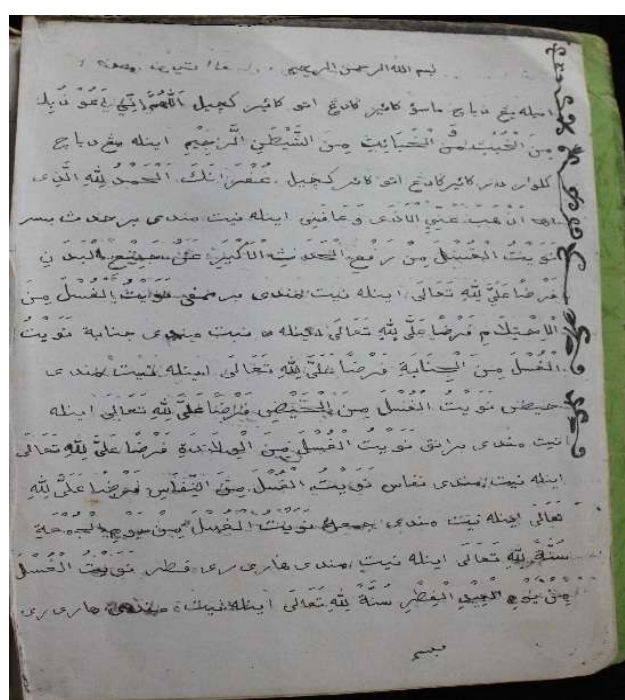

Gambar Naskah Mantiq 